Historic, Archive Document

Do not assume content reflects current scientific knowledge, policies, or practices. 



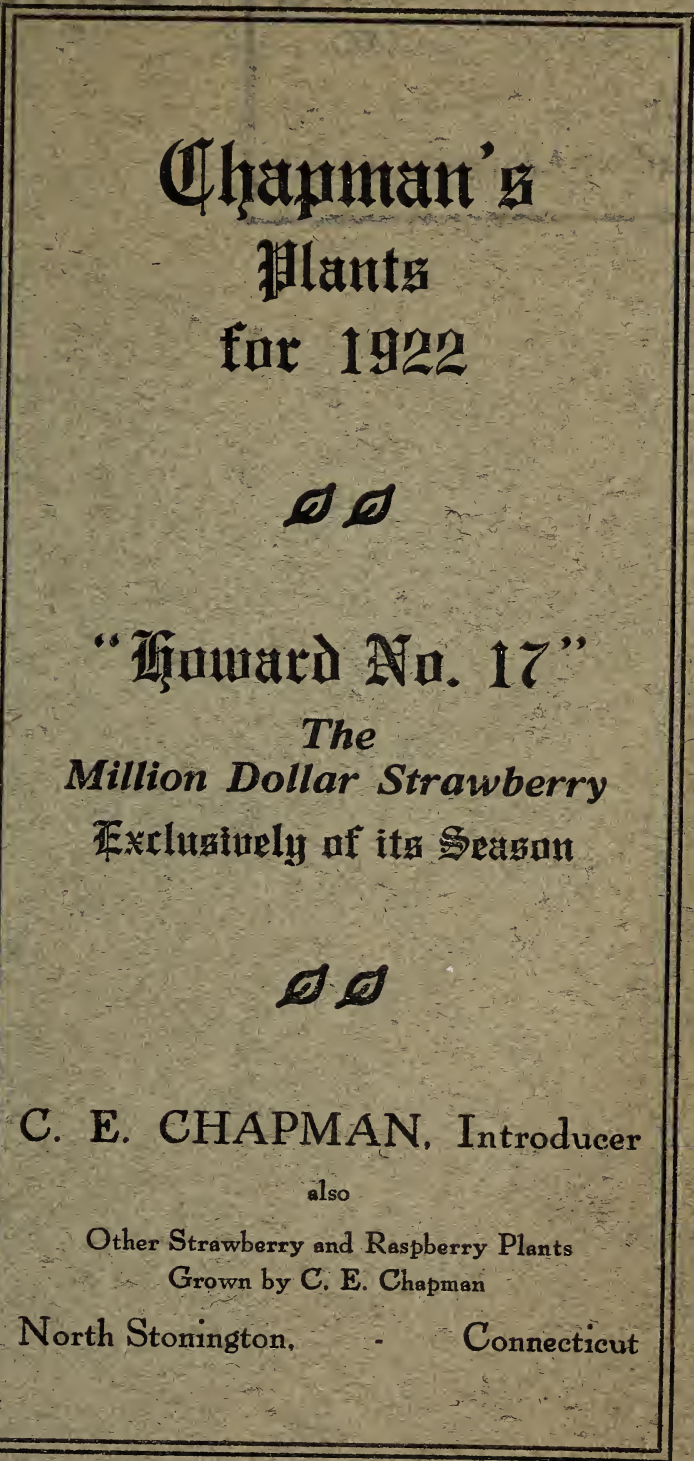




\section{8 .}

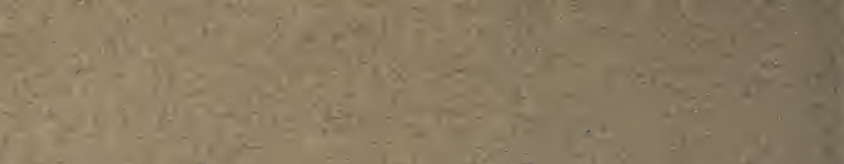

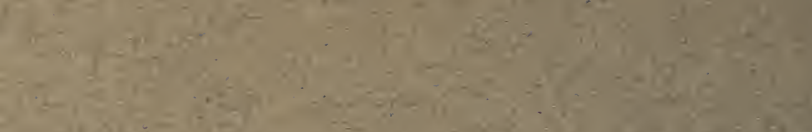

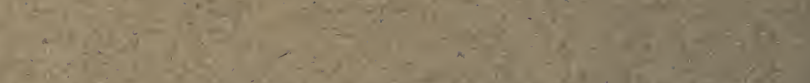

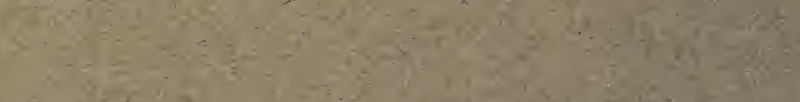

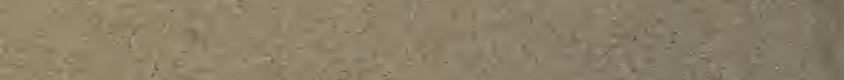

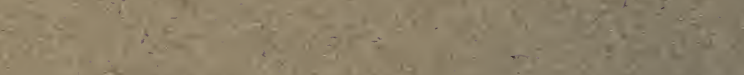

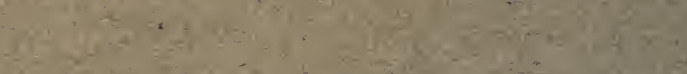

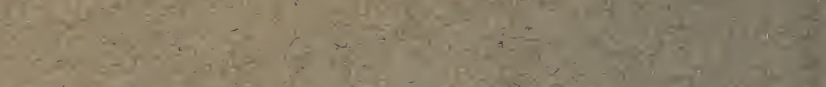

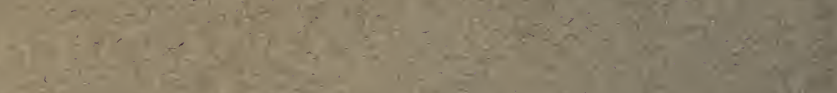

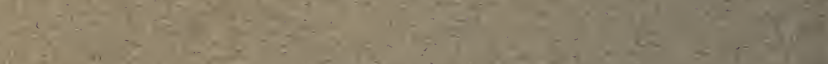

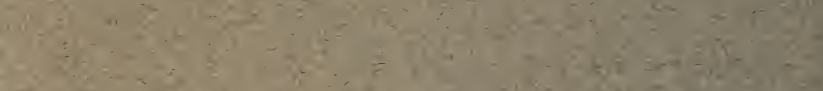

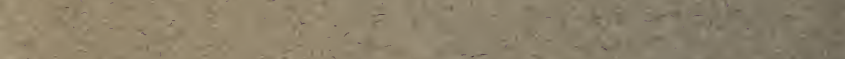

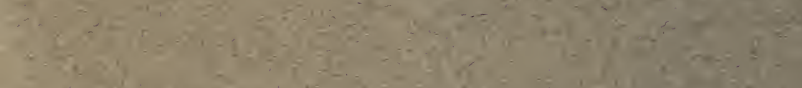

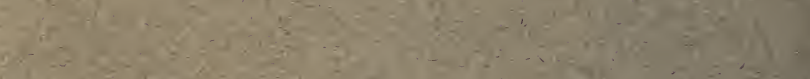

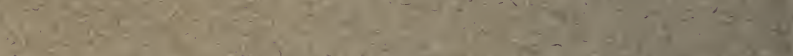

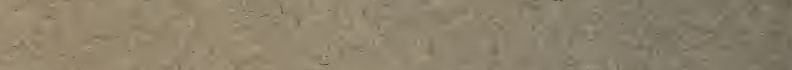

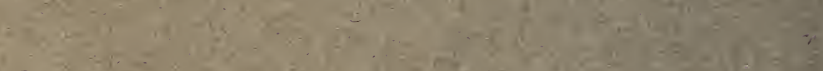

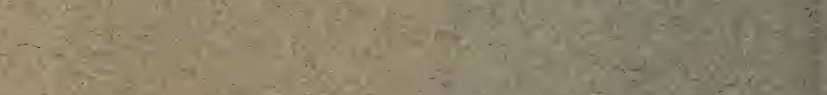

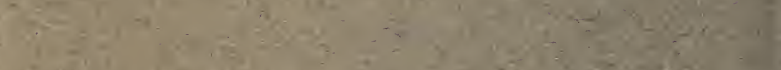

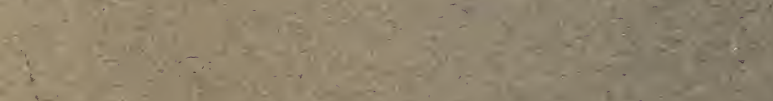

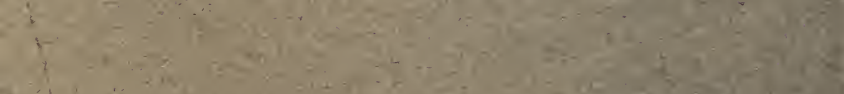

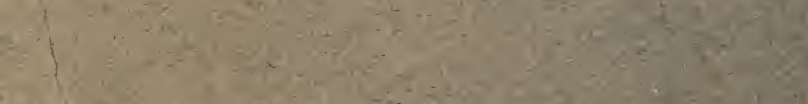

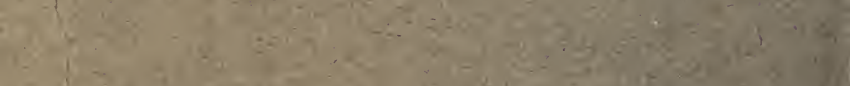

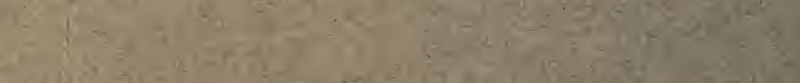

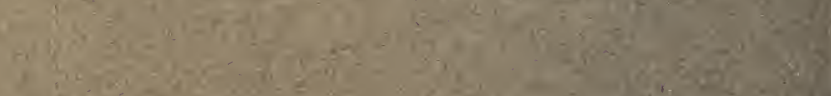

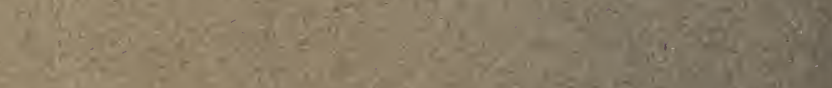

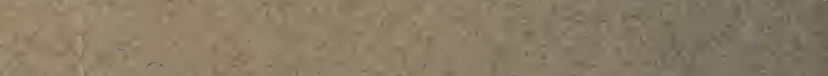

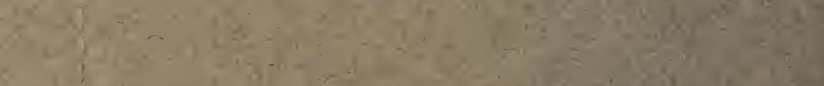

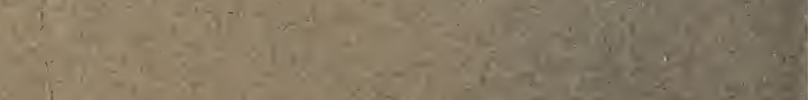

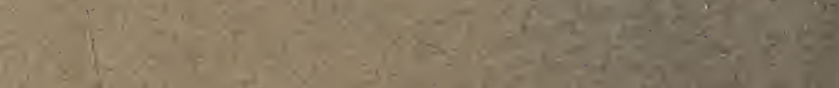

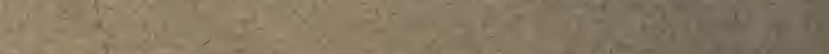

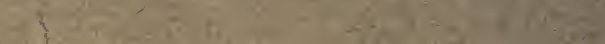




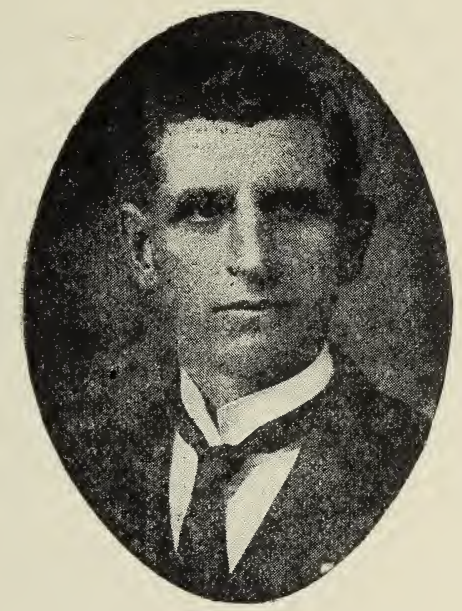

PROFESSOR A. T. STEVENS, of The Connecticut Agricuitural College, who has grown the "Howard No. 17" Strawberry for fourteen years and has never found its equal. 


\section{FRIENDS}

\# GAIN I greet you. Again the "Howard No. -1 17 " is the only variety of its season that I offer, although there are two others I listthey are of different seasons; were this not so there would be no reason to offer them as there is no other variety of its season that compares with the "Howard No. 17." You will learn about them farther along in this booklet. The past season has been the most succesisful in selling plants since I have been in business.

With the largest stock of plants $I_{\text {ine }}$ ever, all were sold and I was obliged to return hundreds of dollars for orders that I was unable to fill, retaining only enough for my own setting and a few for home use, so that for the first time I had no strawberries to market. Some of my customers have written me that their berry crop was damaged greatly by the late frosts that prevailed over much of the country last spring.

Let us hope that this will not occur again. There was no frost damage with me-not a blossom was injured, while only a few miles away on lower ground the crop was cut short.

Strawberries were scarce and prices ruled high-higher even than the year before. Had I fruited my plants I should have received as much and, probably, more than I did for. the plants, but in that case there would not have been the many fields--the many gardens that are set with them which I hope will bring abundant fruitage the coming season to gladden the hearts of those who have set and cared for them.

I have never received so many letters of commendation from my friends as during the past season, some of which are printed herein, but for lack of space many are left out, ibut you 
have $m y$ assurance that all are treasured and I thank you each and everyone for them.

It makes me feel when I receive such kind messages from my friends, that perhaps, after all, I have not lived in vain, for we are told that if anyone has helped others in any way to make life pleasanter-to make life's burdens lighter to bear-to make smoother some of the rough places along Life's pathway, such a life has not been lived in vain. This I have always tried to do and shall continue in the same way to the end.

The above is the bright side of the picture. There is another darker and a sadder side. In September death entered the home almost without warning and removed my beloved wife who had been my companion for many years, sharing with me the griefs and sorrows, the labors and rewards of life, and the home was left lonely. While I have no desire to obtrude $\mathrm{my}$ private griefs and sorrows on the public which has too many of its own to bear, yet I should fail in my duty to the one who has done so much to make my business successful, who has always labored faithfully with me, if I did not pay tribute to her faithful work, for there are many all over this country that have received the benefit of her painstaking labor, for she was always anxious that all should receive their just due. Her work was always well done and she now rests from her labors.

Though life can never be the same again, I realize that though our hearts are saddened by grief and sorrow, yet duty bids us to gather up the broken threads of life to the end, that we may fill up the remaining measure of our days with usefulness and service to others, until we receive the call to join the loved ones gone before. 


\section{Description of Varieties}

\section{"HOWARD No. 17" \\ PERTECT FLOWERS}

This variety which I had the honor of introducing to the public in 1918, had its origin in Hampshire County, Massachusetts, twenty or more years ago.

The originators for some reason declined to let the public have the plants but let a number of State institutions test them. I received my first plants of it in 1916 from Prof. A. T. Stevens, of the Connecticut Agricultural College, and introduced it to the public in 1918, with his permission, being the sole introducer. I found when I first fruited it that I had something better than I had ever seen before in my more than thirty years' experience with strawberries, and thousands have since had the same experience.

It is today the best variety and the most praised of any variety of its season in the country.

Perhaps I can do no better than give the originator's description which, though short, cover the whole subject.

\section{ORIGINATOR'S DESCRIPTION.}

"The greatest market strawberry.

'HOWARD NO. 17.' More dollars are made in growing this wonderful staminate variety than any other. Yield's at the rate of 15,000 quarts per acre. Plants very vigorous with perfect foliage. Berries are large, firm, very beautiful and delicious. Season very early to late. A strawberry without a fault, that will solve the variety question for both home use and market.

This acquisition was produced after thirty 
years of scientific plant breeding and after 25,000 seedlings had been originated."

I have nothing to add to or take from the above. If you wish for more evidence read the testimonials in this booklet. Remember that I as the introducer am headquarters for pure plants of the "Howard No. 17."

Prices for "Howard No. 17" for 1922:

$1,000, \$ 15.00 ; 500, \$ 7.50 ; 250, \$ 3.75 ; 100, \$ 2.00$; $50, \$ 1.00 ; 25,75$ cents. Prepaid. I pay all transportation charges on all plants I sell to destination.

Note-All prices given in this booklet will be found immediately after the description of the variety.

\section{BUSHEL BASKET STRAWBERRY.}

Perfect Flowers. Medium Late.

This variety had its origin in Wayne County, $\mathrm{N}$. Y., and was introdluced to the pubic from there two years ago. The introducer's description covers the whole of a large circular. I can only give it in part and will also give the report of the New York Experiment Station which is always reliable.

\section{Introducer's Description, in Part.}

"This new strawberry was originated eight. years ago by Mr. E. C. Ercanbrack. He first called it the Auburn, then gave it his own name Ercanbrack, under which name it won the Barry Gold Medal given to new fruits of promise. I bought all the plants of Mr. Ercanbrack and grew some of them so large that a bushel basket is not large enough to cover a single plant and my neighbors insisted on calling the new variety the Bushel Basket Strawberry. Thus, by accident rather than by design, the berry is introduced as the Bushel Basket Strawberry. It is an ideal plant maker. The new plants form an average of six inches from the mother plant. It makes the desired matted row without too many surplus plants. 
It accommodates itself to hill culture by reason of its forming multiple firuit crowns. The whole plant denctes a constitution of superior vigor which is necessary to carry its great yield of fruit to maturity. The color of the fruit is a beautiful medium red."

\section{Report of the New York Experiment Station on the Above Variety:}

"Plants numerous, vigorous, perfectly healthy, productive; leaves medium sized, light green; fruit stems long; blossoms in midseason; perfect; ripens in mid-season. Fruit symmetrical, conic plump, necked; apex medium conic; color medium red to light red, medium glossy; seeds much sunken; calyx medium sized, distinctly raised; attractive green; flesh color light red and light red at center; medium juicy, firm with a pleasant, sprightly flavor; good in quality. Pedicels long, berries pick easily; semi-erect; berries not hollow at center; core tender not tough. In diameter runners are thicker than the average. Fruit stems are not brittle. Berries on a two-year-old bed are unusually good in size. Runners tinged red."

I had only a few plants to fruit the past summer of this variety but I was pleased with the showing it made. It ripens a week later than the "Howard No. 17." Many have admired this variety the past summer. Prof. Darrow, fruit specialist at the Connecticut Agricultural College, risited me the past summer and was much pleased with it. He saw it when it was just commencing to ripen its fruit.

It is one of the strongest growers that I ever saw and the plants are very beautiful to look at. I have already more orders for this variety for spring delivery than any other variety I ever had before it was listed as I am now for the first time being, as I believe, the only plant grower in New England who has the plants for sale and while I do not wish for any of my 
friends to "plunge" on it I would be pleased to have you try it. I paid 25 cents apiece for my first plants of it and will sell you one hundred for two-thirds of what I paid for one dozen.

Prices:-Same as "Howard No. 17."

\section{PEARL.}

\section{Perfect Flowers. Very Late.}

This is the latest strawberry that I have ever seen and $I$ have tried them all to date.

In my booklet last year I gave the introducer's description in part. It originated in Indiana, nine years ago. It, like the two preceding varieties, is perfectly healthy-never the slightest disease of any kind.

I did not have. half enough plants of this variety to fill my orders and though I have a. somewhat larger supply this year I expect to be sold out early. Does best on heavy soil as. do all the late varieties. Do not set it on light sandy soil. This year I shall give the report of the New York Experiment Station, taken from their Bulletin for 1918, as it gives it just as I have found it and their reports are reliable.

"Plants numerous, large, healthy, productive; leaves large, thick, medium green; fruit matures very late; very large, retaining size well as the season advances, flesh well-colored to the center, juicy, very firm, sprightly; good in quality. Plant habits good; the late-blooming flowers. are not subject to frost injury; fruit matures among the very latest varieties, one of the best. of shippers, as well as choice in size of berry, attractive in appearance except for a number of berries undeveloped at the apex; worthy of test for a sprightly, late variety of high quality."

Prices:-Same as "Howard No. 17."

\section{EVERBEARING STRAWBERRIES.}

Progressive bears the most fruit.

Superb bears the largest fruit.

Prices same as "Howard No. 17." 


\section{RASPBERRIES}

Winfield Black Raspberry, the Wonder in Berry Production.

It is pleasing to be able to indorse the description given a new fruit as given by the introducer as I am able to do of the above named Black Cap Raspberry.

For years the Plum Farmer has been the leading Black Cap Raspberry the country over. I was among the first, if not the first, to grow it in New England and at one time was the largest grower of it in New England, growing acres of it and I probably did more to introduce it than anyone except the originator. I shipped the plants into more than half the United States, sending them into every state from Rhode Island to California inclusive, and as far south as Louisiana, selling the plants in 5,000 lots to dealers and at retail to growers. I shipper the originator, Mr. L. J. Farmer, of Oswego County, N. Y., 5,000 plants at one time for his trade. Up to the introduction of the Winfield Raspberry it was the best one ever grown but the Plum Farmer has met its superior in every point. It was introduced from Kansas City, Missouri.

The introducer's description follows:

\section{WINFIELD BLACK RASPBERRY.}

"The king of them all.

This grand new black cap originated at Winfield, Kansas, and after 10 years of testing has proven itself the king of black caps. In hardiness and productiveness it is unexcelled by any other variety. It has never"winter-killed through 10 years of fruiting and stands extreme drouths. The fruit is of enormous size, single berries covering a quarter. Four to six great clusters are produced on each cane, averaging from three to six quarts to the plant. Fruit is firm, sweet, rich and juicy. Seeds very small. 
Bush is healthy and vigorous, making robust, stocky canes easily supporting their heavy load; not troubled with rust. Succeeds on all soils. Unexcelled for market."

Although the above is the description of another party more than a thousand miles from New England, yet its behavior here is very close to his description. I consider it the Supreme variety, occupying the same place among Black Cap Raspberries as the "Howard No. 17" does among strawberries-the best one of all. I started with only three plants of it a number of years ago and have fruited it a number of times but have never had any surplus plants to offer until now and I cannot sell more than 50 plants to one customer as my stock is not large and $I$ wish to get it distributed among as many as possible.

A member of my family has picked at one picking, $2 \frac{1}{2}$ quarts from one bush set the year before and there were a number of pickings before and after this. I picked berries of this variety the past summer on the new canes of the present season's growth that measured more than three-quarters of an inch in diameter. These big, juicy, meaty fellows would hardly be able to recognize their. remote ancestors-the wild Black Caps of our childhood days that we used to gather in the fence corners, and by the side of the stone walls. My advice to all who have any use for a Black Cap Raspberry either for home use or market is to get a start with this "King of All the Black Caps." Its season is the same as the Plum Farmer. I have priced them in small quantities to accommodate all, and the prices are less than the introducer quotes them in his catalog, and I am the only grower in New England who will offer this variety the coming spring.

Prices:-One plant, 15 cents; 3,35 cents; 6, 60 cents; $12, \$ 1.00 ; 25, \$ 1.75 ; 50, \$ 3.00$. Postpaid. 


\section{ONTARIO RED RASPBERRY.}

This new Red Raspberry was originated at the Geneva, New York Experiment Station, and distributed by the New York Fruit Producers' Association, connected with the station. I received my first plants directly from them. They only sold them in dozen lots and four dozen. was all I could buy from them. I will give their description which is very conservative.

The introducer's description follows:

\section{ONTARIO RED RASPBERRY.}

"A second generation of Superlative crossed with Louden. This seedling has made a favorable impression for several seasons. The plants are very hardy, vigorous; develon a medium number of suckers and are very productive. Fruit matures in early mid-season, earlier than Cuthbert, later than June, Perfection or Marlboro. The berries are large and their size is well retained throughout the season. A good shipper. Flesh is nearly as sweet and aromatic as Cuthbert. Good in flavor and quality."

I have found it just as described. Plants made a growth of six feet with me the first season on good soil. I have only a few plants to spare and I shall sell them while they last at the same price that I paid for them by the dozen and they are strong, vigorous plants.

Prices:-One plant, 15c; 3 plants, 35c; 6 plants, $60 \mathrm{c} ; 12$ plants, $\$ 1.00$.

\section{Important.}

The raspberries start to grow very early in the spring and should be ordered early. If not ready to set them on arrival you can heel them in when they may be kept until ready to set. Order early for best results. 


\section{TESTIMONIALS}

New York Agricultural Experiment Station, Geneva N. Y., April 3, 1921.

C. E. Chapman, North Stonington, Conn., Dear Sir:-I wish to acknowledge for the Station the receipt of package containing plants of the "Howard No. 17" strawberry for testing. The shipment arrived in excellent condition and I am pleased to note the remarkable vigor of the plants forwarded. Very truly yours,

$$
\begin{aligned}
& \text { O. M. TAYLOR, } \\
& \text { Associate Horticulturist. }
\end{aligned}
$$

$$
\text { Putnam, Conn., May 3, } 1921 .
$$

Dear Mr. Chapman:-Plants arrived today in fine condition and are excellent plants in every way. I have planted strawberry plants before and have examined thousands of plants, and these are the best rooted I have ever seen.

$$
\text { Yours very truly, }
$$

HERBERT J. MILES.

Mr. Miles is Federal Plant Inspector for Eastern Connecticut.

Wendell, N. H., May 23, 1921.

Dear Sir:-Received the plants and I am more than pleased with them. They are the best plants I have ever bought and I have bought a good many. Yours truly,

E. A. NUTTING.

Hudson, Mass., April 28, 1921.

Dear Sir:-The strawberry plants arrived in good condition last night and a better looking lot of plants I have never seen. Yours truly,

N. F. BALTHAZAR. 
Laconia, N. H., May 5, 1921.

Dear Sir:-Please ship Monday, if possible, 1,500 "Howard 17." I had plants of you last spring and they were "rippers." Find inclosed check for $\$ 22.50$. Yours truly,

T. J. GRANT.

South Manchester, Conn., April 28, 1921.

My Dear Mr. Chapman:-I want to say the 1,000 "Howard No. 17" plants came in good shape and I want to thank you for being so prompt in your delivery. They certainly were the best looking plants I ever put out, such large crowns. Am surely pleased with them. You may book me for the future.

Very truly yours,

M. St. CLAIR BURR.

In order to have the large crowns that $\mathrm{Mr}$. Burr mentions it is necessary for the plants to have plenty of room to develop and plenty of fertilizer. The crown of the plant, the fleshy part from which the roots and leaves proceed, is where the nutriment is stored up to produce the big red berries or if they are set out and blossoms removed the big strong plants for the next season's fruiting. Plants that are grown too thick in the row cannot produce strong crowns and the plants grown from them will be weak and their fruit will be small and inferior. Some of the plants I sent out last season, had crowns as thick as a man's finger. One such plant is worth more than a dozen slender plants with crowns the size of a knitting needle, such as I have sometimes received from nurseries that claimed to send out the best plants. To set such plants is to throw away your time, money and income from them.

West Willington, Conn., May 18, 1921.

Dear Mr. Chapman:-The plants came this morning in fine shape. They have the best 
roots of any I ever saw. I dug holes with a hoe each way leaving the center the highest making the holes deep enough so the extreme ends of the roots would still point downward, then spread the roots each side of the hill and filled in. Then I watered them and hoed dry earth over the watered place. In my 85th year I am having the happiest time of my life. With best wishes, I a.m yours cordially,

\section{GEORGE A. COSGROVE.}

Mr. Cosgrove is the well known writer for the Rural New-Yorker, and also has lectured all over the country on Poultry subjects. He wrote me again in August that the plants lived and had done well as we should expect they would after they had received such care in setting them. There are very few men in the country who are setting out strawberry beds in their 85th year, and I hope he will live to enjoy his strawberries till he reaches his century mark at least, and as much longer as possible.

R. C. Cookingham, Florist, Carnations a Specialty,

Ellenville, N. Y., June 19, 1921.

Dear Sir:- "The Howard No. 17" strawberry plants ordered from you this spring came in good order. They were without exception the best plants that I ever bought and I have been in the business 30 or more years.

Yours truly,

R. C. COOKINGHAM.

F. L. True, Grower of Small Fruit, Plants and Fruit Trees,

Adams Basin, N. Y., May 6, 1921.

Dear Sir:-Your "Howard 17" are the finest stock that I have ever received and I have great hopes for it as a fruiting variety.

Very truly yours,

H. L. TRUE.

I don't think Mr. True will be disappointed next summer at fruiting time. 
Pulaski, N. Y., April 18, 1921.

Dear Sir:-Received plants in fine shape today. Have them heeled in waiting for winter to let go. Yours truly,

DAVID P. ROGERS.

Castleton, N. Y., May 2, 1921.

Dear Sir:-I received the plants and set them out and never lost a plant and they are growing fine. Yours respectfully,

CLINTON KELLAM.

New Britain, Conn., May 1st, 1921.

My Dear Mr. Chapman:-Your plants were lcertainly fine. I had some from Salisbury, Mld, last week that looked as if they had been out of the ground for a week or more. The leaves all died off of one kind, nothing but a little green in center alive now; don't know how they will turn out and they came from a dealer that advertises pretty big at that. I only had a small quantity-not enough to make a fuss about as far as money consideration goes but I was disappointed. I thank you for your prompt service and excellent plants.

I remain yours truly,

R. D. NORTON.

Standish, Mass., April 25, 1921.

Dear Sir:-People in this vicinity say that I am fussy because I insist on getting what I pay for, and if I don't get it I am apt to kick hard; at any rate some hear from me. When I get a square deal I am pleased to say so. Therefore, I am writing to say how pleased I am with the 2,000 strawberry plants you sent me. They are the most uniformly good plants 
that I have ever bought and I have bought many thousands. Yours sincerely,

J. R. TALLMAN.

Waterdown, Ontario, Canada, March 7, 1921.

Dear Sir:-I was looking at my "Howard No. 17" plants yesterday that I purchased of you last year. They have wintered well. They were the only strawberry I grew last year that was absolutcly fire of all disease. Find inclosed money order for $\$ 7.50$ for 500 more of the "Howard No. 17." Yours truly,

\section{J. MULLOCK.}

A. B. Willard, Architect and Builder, Madison, Conn., April 16, 1921.

Dear Mr. Chapman:-The "Howard No. 17" plants arrived and were set today. I need 100 more to complete the plot. Please find amount inclosed. The plants were something grand. Many thanks. Yours truly,

A. B. WILLARD.

The "Howard No. 17" in Ohio.

The Cassel Nursery,

Mantua, Ohio, Aug. 17, 1921.

My Dear Mr. Chapman:- "Howard No. 17" proves to be the best perfect blossom strawberry $I$ have ever fruited in forty years growing strawberries. When the berries were half-grown we had two freezes which formed ice one-fourth inch thick. Everything was frozen stiff. When the first berries begun to ripen a heavy hail storm pounded down the foliage flat, but in spite of the adverse conditions we had a splendid crop of "Howards." The plant is large and perfectly healthy. The berries will grade 90 per cent. fancy and for such a large berry this is 
something unusual. Until something better comes we shall use this variety for main crop.

The Pearl strawberry plants you sent us last spring came through without delay and I believe everyone is growing. They were the only rcally good strawberry plants we received last spring. Yours truly,

M. CASSEL.

Beulah Farm,

West Hartford Vt., May 3, 1921.

Dear Sir:-I am so much pleased with the good vigorous plants sent that I herewith send check for another 250 of the "Howard No. 17" strawberry plants for immediate delivery.

Yours truly,

MRS. GEORGE W. HANDY.

Falmouth, Mass., April 13, 1921.

Dear Sir:-Your "Howard No. 17" is a wonderful market berry and from the 500 plants you shipped me we picked last season over 1,000 baskets, in spite of dry weather and no irrigation. Yours sincerely,

L. C. JONES, M. D.

The “Howard No. 17" in Arkansas.

Mena, Ark., June 20, 1921.

Dear Sir:-I purchased from you 100 "Howard No. 17" strawberry plants in May, 1919, and made report on same through the Mena Evening Star, May 21, 1920. From the 100 plants purchased I set one row 150 feet long and they made a good row. Commenced picking April 15, 1921. Berries were large, highly colored and quality the best and most productive of any berry I ever fruited. I have been picking berries for nearly six weeks and 
as we have had plenty of rains at times needed, I am now picking from the same plants the second crop and it is nearly as large as the first crop (second crop this year).

F. S.-I find that the "Howard No. 17" is red to the center. In the report last year it was white but it was on account of the cold weather that the berries did not ripen through like they did when the hot sun ripened them up well. I find the second cron of "Howard No. 17" red to the center. Very truly yours,

C. H. WEBSTER.

I stated in my booklet last year that the "Howard No. 17" was white to the center. The conditions were the same here as Mr. Webster mentions. The past year the berries here were red to the center which is their normal color.

Williamburg, Mass., May 11, 1921.

Dear Sir:-Inclosed find money order for $\$ 15.00$ for which please send me 1,000 "Howard No. 17" strawberry plants. I was going to send to another grower for them as I could get them for less but after reading Mr. Arthur N. Peckham's letter in your booklet telling what nice piants he got of you, I decided to get them of you even if they cost more as I want the best that can be bought as I know I can get better returns from them.

Yours truly,

H. W. RICE.

The letter to which $\mathrm{Mr}$. Rice refers is again printed for the benefit of those who did not see my booklet last year.

The letter follows: 
Kingston, R. I., July 8, 1920.

Dear Sir:-Last spring I got of you 3,000 "Howard No. 17" strawberry plants. I also purchased 6,000 of the same variety of two other men at less than half the price per thousand that you asked, but I rather have your plants if they cost five times the price I paid for theirs.

Inclosed please find check for $\$ 10.00$ for which please send me that amount's worth of "Howard No. 17" to plant over where the other men's plants died. Yours truly,

ARTHUR N. PECKHAM.

In other words 1,000 of my plants were worth as much as 5,000 of the others he bought. Further comment is unnecessary.

I have many more testimonials that I might give did space permit, but they would be of the same tenor and it is not necessary.

I have made my prices as low as I can afford to for the grade of plants I sell. The plants I offer this season have cost me as much to grow as they did three years ago when I sold plants for $\$ 25.00$ per thousand and everything that enters into the business costs as much now as then and some things cost more. I shall have to pay as much for labor the coming season as I ever did or go without it. Printing costs as much and advertising costs more.

Since I have been in the plant business I have sent out thousands of orders, and I have never received one complaint of the quality of my plants, a fact which is very pleasing to me. 
I sell only one grade of plants-the best-at a fair price.

A good article is worth a fair price while a poor article is dear at any price.

Faithfully yours,

C. E. CHAPMAN,

Introducer the "Howard No. 17," the Million Dollar Strawberry.

North Stonington, Conn.

Telephone 43-14, Mystic Exchange.

Note-All orders will be sent by parcel post, charges prepaid. Parcel post is quicker, safer, better than express shipment. Out of hundreds of orders sent out last year, only one was lost and that was a small order of fifty strawberry plants sent to Milford, N. H. 


\section{TERMS AND ADVICE}

No goods shipped until paid for in full. I will, however, book orders if at least one-third the amount of the order is sent when ordering. as an evidence of good faith, the balance to be sent when you order the goods shipped. No attention will be paid to C. O. D. orders.

\section{WHEN TO ORDER}

Any time after you receive this booklet. I have already quite a number of orders booked for next season, one being for 5,500 plants, enough to set an acre.

Your plants will be reserved if accompanied with remittance as above stated. Make remittance in any way that is most convenient.

Note-All the strawberries listed herein are perfect-flowered and require no other variety set with them for fruiting results.

Shipping season begins in April and extends as long as orders are received. 


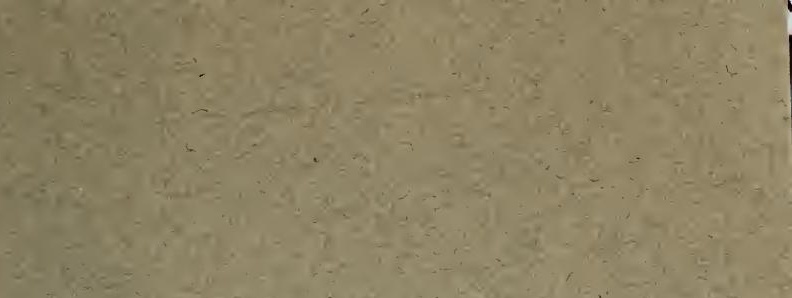

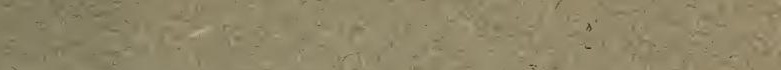
$x^{2}+x^{2}+x^{2}+x^{2}+x^{2}$

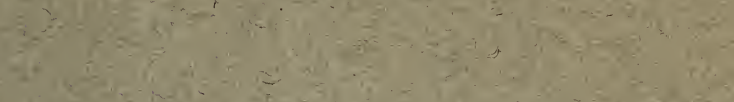

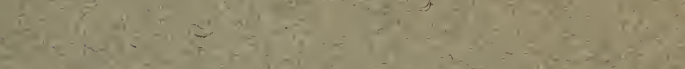

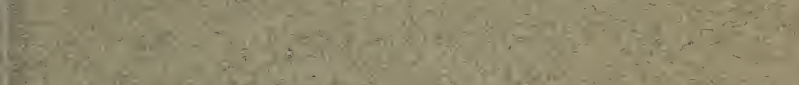

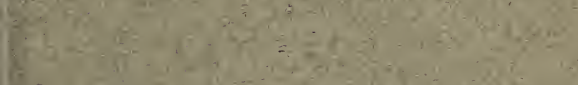

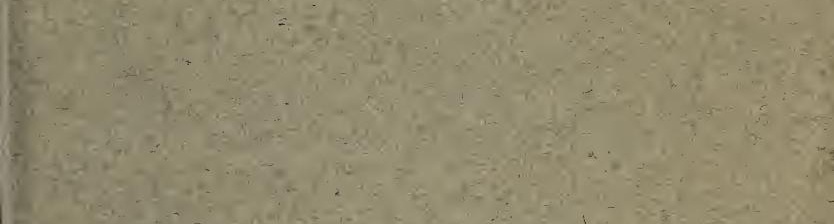

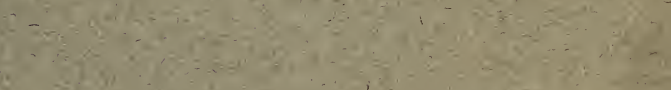

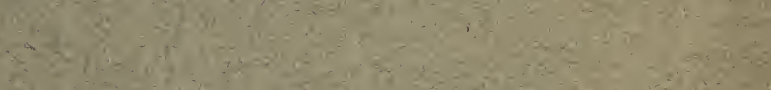

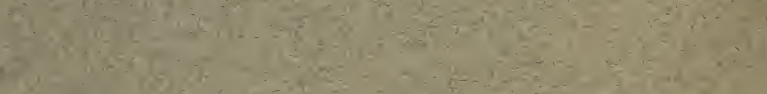

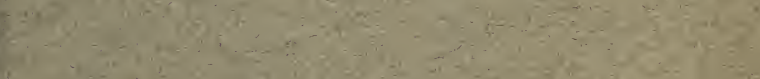

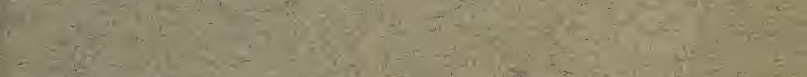

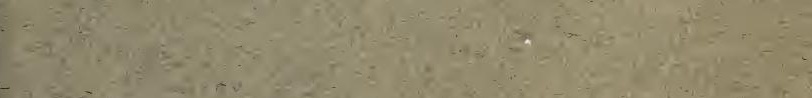

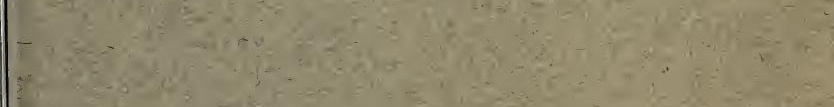


